\title{
Dramanın Duygusal Zeka Gelişimine Etkisi
}

\author{
Sibel GÜNEYSU ${ }^{1}$ \\ Belkıs TEKMEN ${ }^{2}$
}

Başkent Üniversitesi

\begin{abstract}
$\ddot{O z e t}$
Bu çalışmada, günümüzde önemi giderek artan dramanın duygusal zekanın gelişimine etkisi incelenmektedir. Çalışmaya Başkent Üniversitesi Ĕ̈itim Fakültesinde drama dersini alan otuz lisans öğrencisi katılmaktadır. Nitel araştırma tekniklerinden toplu görüşmeler, portfolyo değerlendirme, video kayıt ve gözlem teknikleri kullanılarak drama eğitiminin kişilerin duygusal zeka ve iletişim becerileri üzerindeki etkilerinin ortaya çıkarılması amaçlanmıştır. Duygusal zekanın gelişimi için sağlıklı bir iletişime gerek duyulduğu gibi, iyi ve güvenilir bir iletişim için de duygusal zekanın gelişimine gereksinim vardır. Birbirini tamamlayan bu iki bileşen, duygusal zeka ve iletişim becerileri, drama eğitimi öncesinde, süreç boyunca ve sonrasinda çok yönlü ve derinlemesine araştırılmıştır. Bireyin kendi potansiyelini tanıması ve gelişme kaydedebilmesi için en elzem bileşenlerin başında kişinin duygularının farkında olması, bunu ifade edebilmesi ve sağllklı iletişim kurması gelir. Aynı zamanda iletişimi sağllklı hale getirebilmek için de duygunun açık ve doğru şekilde iletilmesi ve alıcı kişinin de bunu tanımak konusunda yeterliliğin olması gerekir. Drama çalışmalarının özünde birlikte üretme ve paylaşma isteği olduğundan, birbiriyle etkileşim içinde olan ve birbirlerini besleyen bu iki bileşenin de gelişmesi için uygun bir ortam oluşmaktadir.
\end{abstract}

Anahtar sözcükler: Duygusal zeka, iletişim becerileri, eğitimde drama

\begin{abstract}
In this study, the effect of drama on the development of emotional intelligence, which gains more importance nowadays, is investigated. Thirty undergraduate students taking drama course in the Education Faculty of Baskent University are participated in the study. Qualitative research methods, which are group interviews, observations, video recordings and portfolio evaluation, are used to understand the effects of drama education on individuals' emotional intelligence and communication skills. Developing emotional intelligence needs a healthy communication, whereas a healthy and reliable communication needs a development in emotional intelligence. These two complementary pieces, emotional intelligence and communication skills, are analyzed thoroughly before, during and after the drama education. Being aware of the selfemotions, expressing them and establishing a healthy communication are the most essential components of knowing ones self potential and improving it. Since there is the idea of producing and sharing in the heart of drama studies, it makes a suitable environment for the development of emotional intelligence.
\end{abstract}

Keywords: Emotional intelligence, communication skills, drama in education

\footnotetext{
${ }^{1}$ Prof. Dr., Başkent Üniversitesi Eğitim Fakültesi, sibelg@baskent.edu.tr

${ }^{2}$ Araş. Gör., Başkent Üniversitesi Eğitim Fakültesi, tekmen@baskent.edu.tr
} 


\section{Giriş}

Bireyin kendi potansiyelini tanıması ve gelişme kaydedebilmesi için en elzem bileşenlerin başında kişinin duygularının farkında olması, bunu ifade edebilmesi ve sağlıklı iletişim kurması gelir. Aynı zamanda iletişimi sağlıklı hale getirebilmek için de duygunun açık ve doğru şekilde iletilmesi ve alıcı kişinin de bunu tanımak konusunda yeterliliğin olması gerekir. Drama çalışmalarının özünde birlikte üretme ve paylaşma isteği olduğundan, birbiriyle etkileşim içinde olan ve birbirlerini besleyen bu iki bileşenin de gelişmesi için uygun bir ortam oluşturur.

Duygusal zekanın köklerini 1920 lerden Thorndike' tan aldığı görülmektedir. 1992 de Ruisel' in “ insanları anlama ve ilişki kurma yeteneği” diye tanımladığı sosyal zekayı Thorndike "Kadınları, erkekleri,erkek çocukları, kız çocukları anlama ve yönetme, insan ilişkilerinde akıllıca davranabilme yeteneği" olarak tanımlamıştır. Howard Gardner ise 1983 de ortaya koyduğu "Çoklu Zeka" Teorisinde kişiler arası ve içsel zekalardan bahsetmekte ve bu ikisini sosyal zeka olarak vurgulamaktadır.

New Hampshire Üniversitesinden John Mayer ve Yale Üniversitesinden Peter Salovey Çoklu Zeka Teorisinden etkilenerek 1990 da duygusal zekayı "Bireyin kendinin ve diğerlerinin duygularını tanıma, ayırt edebilme, yönetebilme ve bu bilgiyi bireyin düşüncelerini ve eylemlerini yönlendirebilmesinde kullanabilme yeteneğini içeren bir çeşit sosyal zeka" olarak tanımlamışlardır. Mayer ve Salovey’e göre ise duygusal zeka, kişinin kendisinin ya da başkasının duygularını temsil etmek için aralarında seçim yapmaya ve bu bilgileri kişinin düşüncelerine ve davranışlarına rehberlik etmesinde kullanmaya yarayan bir olgudur. Duygusal zeka kişinin duygularını kontrol etme, bunlar arsında seçim yapabilme ve bu duygularını hayatına yön vermede kullanabilme becerilerini içeren sosyal zekanın bir tipidir (Mayer ve Salovey, 1993). Benzeri tanımlamalarda bulunan Daniel Goleman'ın 1995 de yayınladığı "Duygusal Zeka" adlı kitabındaki açıklamalarında bu iki psikologdan etkilendiği görülür (Güneysu, Çağlayan ve Kaygısız, 2005).

Duygusal zekanın temel alındığı bu çalışmada da aşağıdaki tanımlamalar esas alınmıştır:

1.Kişinin duygularını bilmesi (öz farkındalık):Kendini gözleme ve bir duyguyu oluştuğu anda tanıyabilme, andan ana değişen duyguları ele alabilme yeteneği. Duygularını en iyi tanıyan insanlar yaşamlarını en iyi yöneten insanlardır. Kişisel kararları hakkında gerçekten ne hissettiklerinden eminlerdir.

2.Duyguları yönetme: Bir duygunun arkasında ne olduğunu kavrama, karamsar, engellenmiş veya tedirgin yada kaygılı olduğumuzda kendimizi sakinleştirebilme kapasitesi.

3.Kişinin kendini güdeleyebilmesi: Duyguları herhangi bir amacın hizmetine sokmak üzere harekete geçirmek; duygusal öz-kontrol; doyumu erteleme ve çekiciliğe kapılmama .

4.Empati: Diğerlerinin duygularına ve ilgilerine duyarlı olma ve onların açısından bakabilme; farklılıkları takdir edebilme.

5.İlişkileri ele alma: Diğerlerinin duygularını yönetebilme; sosyal yeterlik ve sosyal beceriler. 
Duygusal zeka, insanın duygularının ne kadar farkında olduğu, bunları nasıl daha verimli kullanabileceğini açıklayan değişken bir faktördür. Duygusal güçleri gerektiği gibi kullanmasını bilen, yani duygusal zekası yüksek insanlar, özel ve mesleki hayatlarını kendilerine kolaylaştırmışlardır. Çevresindekilerin ve kendi hislerinin farkında olmak, güncel yaşamda karşılaşılan sorunların üstesinden gelebilme potansiyelini artırmaktadır (Konrad, 2001).

Toplumsal birer varlık olan insanlar yaşamları boyunca sürekli başkalarıyla iletişim halindedir. İletişim aracılığıyla hem kendileri hem de iletişim halinde oldukları kişiler hakkında yeni bilgiler elde ederler. Edindikleri bilgiler ışığında kendilerine ilişkin yeni yapılar oluştururlar ve bu yapılar çerçevesinde iletişimlerini sürdürürler. Her bireyin başkalarıyla kurduğu ilişkiler kendine özgü olduğundan, her bireyin kendine özgü yapılar oluşturacağı varsayılır. Bu yapıların, bireyin iletişim tarzının nasıl olacağını belirlemede önemli bir yerinin olduğu söylenebilir. İletişim tarzı,bireyin kendisini,başkalarını ve dış dünyayı algılama tarzı ile yakından ilişkilidir. Algılama tarzının oluşumu, bireyin sahip olduğu değerlendirme gücü,yakın çevresinden aldığı mesajlar ve bu mesajları yorumlamasının etkileşimi ile ilgilidir. Algılama tarzının oluşumu, bireyin sahip olduğu değerlendirme gücü, yakın çevresinden aldığı mesajlar ve bu mesajları yorumlamasının etkileşimi ile ilgilidir. Bunun yanında,bireyin çevresindekilerin iletişim tarzları da önemli bir referanstır. Bu nedenle, iletişim tarzının öğrenilen bir yönünün de olduğu görülmektedir (Çam, 1997).

Duygusal zeka ve iletişim becerilerinin gelişiminin desteklenmesinde pek çok yöntem kullanılabilmektedir. Bu amaçla günümüzde okul öncesi eğitimden başlayarak üniversite ve lisans üstü eğitime kadar bütün eğitim kademelerinde kullanılan yöntemlerden biri de eğitimde drama çalışmalarıdır. Yalnızca eğitimde değil başka birçok alanda da drama önem kazanmıştır. Sihirli bir yöntem olarak nitelendirilen drama ile insanlar kendilerini daha iyi tanıyabilmekte, yeteneklerini ortaya çıkarabilmektedirler. Dramada temel amaçlar arasında katılımcının kendini diğer bireylerin yerine koyması, böylece de kendisini ve çevresini daha iyi bir şekilde tanıyabilmesi, anlayabilmesi yer almaktadır (Güneysu, 1999; Öztürk, 1999; Sağlam, 1997).

Drama, önceden yazılı bir metin olmadan, katılımcıların kendi yaratıcı buluşları, özgün düşünceleri, anıları ve bilgilerine dayalı olarak oluşturdukları eylem durumları ve doğaçlamalardır (San, 1999). Çocuk oyunlarından ve benzer etkinliklerden yola çıkarak, değişik yaşam durumlarını canlandırma, olayları yeniden yaratıp irdeleme, bu yaşam durumlarından bilgilenme ve öğrenmeye geçme drama çalışmaları kapsamında yer almaktadır. Farklı yaşantıları tanıma, farklı rollere girerek farklı olay ve durumlarla ilgili deneyim kazanma, yaşamın çok yönlü algılanmasını ve araştırma isteğinin gelişimini sağlama, yaparak, yaşayarak öğrenme, öğrenilenlerin kalıcı olması drama çalışmaları sonucunda bireylerde olması beklenen kazanımlar arasında sayılabilir. Bu kazanımlar dikkate alındığında dramanın bireylerin gelişiminde önemli bir etkisinin olduğu söylenebilir( Akyol, 2003).

Çağdaş eğitim anlayışına göre eğitim yaşantısı süresince öğrencilerin akademik becerilerinin gelişmesi yanı sıra sosyal becerilerinin geliştirilmesine de önem verilmektedir. Bu bakış açısıyla eğitimde dramanın kullanılması Carl Rogers (1994) in hümanistik ve birey merkezli felsefesiyle uyum 
göstermektedir. Öğretmen didaktik ve otoriter güç sembolü olma statüsünü bırakarak sınıfa girdiğinde ve kontrolü geçici olarak öğrencisinin yaratıcı enerjisine verdiğinde, drama eğitici bir araç olarak kişisel gelişimi, kişisel farkındalığı, potansiyeli ve yeterliliği güçlendirici etkisini göstermektedir (Wasylko and Stickley, 2003). Bunların yanında çatışma yönetimi ve iletişim becerilerinin gelişmesinde katkı sağlamaktadır (Reiseborough 1993). Dramanın eğitimde kullanılması, duygusal geliş̧imin ileri aşamalarından biri olarak değerlendirilen empati becerisi için gerekli anahtar etkinliklerden biri olarak öğrencinin karşısındakinin beden dilini anlamasını ve doğru tepki vermesini kolaylaştırmaktadır (Andersen and Warren, 1995).

Eğitimde dramanın kullanılması öğrencilerin etkin katılımını gerektirmekte ve etkinlikler genelde sağ beyini aktive eden ve sürekli takınılan ifadeleri bir yana bırakarak yeni ve orijinal denemeler yapabilmelerine firsat vermektedir. Bu sayede deneyim ve duyguların paylaşımı farklı bakış açılarını anlamayı ve değerlendirebilmeyi geliştirmektedir. Wasylko and Stickley (2003) nin hemşirelik eğitiminde dramanın kullanılması ve duygusal zeka gelişimini takip ettikleri çalışmalarında eğitimde dramanın kullanılmasının öğrencilerin mesleki ve kişisel gelişimlerinde olumlu etki sağladığı görülmüştür. Aynı çalışmada öğretmenlerin de eğitimde dramanın kullanılmasının empati gelişimine katkısına inanarak özellikle iletişimin önemli olduğu bu tip mesleklerde öğrencilerine gereken özgür öğrenme ortamını sağlamaları gerektiği savunulmuştur.

Daha küçük yaşlardaki öğrenci gruplarıyla yapılan eğitimde drama ve etkileri çalışmalarında da benzer olumlu etkiler gözlenmiştir. Wright (2006) da 123 katılımcıya yönelik gerçekleştirdiği 10 hafta süren oyun temelli drama programının sonuçlarında 11,5 yaş ortalamasına sahip öğrencilerin bu yöntemle bireysel ve sosyal gelişimlerinde öntest ve sontest sonuçlarında anlamlı farklılık bulmuştur. Özellikle rol alma ve sözel ifade becerisi gelişiminde dört ayrı test sonucuna göre olumlu etki gözlenmiştir. Aynı şekilde Ulaş ve Topal (2006) dramanın 4.sınıf öğrencilerinin sözel becerilerindeki etkisini araştırmış ve geleneksel yöntemin uygulandığı kontrol grubuna göre drama etkinliklerinin daha etkili bulunmuştur. 


\section{Amaç ve Yöntem}

\section{Çalışma Amacı}

$\mathrm{Bu}$ çalışmanın amacı drama dersinin, öğrencilerin duygusal zeka ve iletişim becerilerinin gelişimine katkısını incelemektir. $\mathrm{Bu}$ amaçla, drama dersinin öğrencilerin duygusal zeka becerilerinde oluşturduğu değişim ve gelişim araştırılmıştır.

\section{Çalışma Deseni}

Amaçlı örnekleme yöntemlerinden kolay ulaşılabilir durum örneklemesinin uygulandığı bu çalışma, Ankara ili Başkent Üniversitesi Eğitim Fakültesi Okulöncesi Öğretmenliği 2007-2008 eğitim-öğretim akademik yılı bahar döneminde ikinci sınıfına devam eden 30 lisans öğrencisi üzerinde yürütülmüş̧ür. Diğer araştırma türlerinden ayrılan yönlerinden yola çıkarak, durum çalışmasının "nasıl" ve "niçin" sorularını temel alan, araştırmacının kontrol edemediği bir olgu ya da olayı derinliğine incelemesine olanak veren bir araştırma yöntemi olduğunu söylemek mümkündür (Yıldırım ve Şimşek, 1999).

$\mathrm{Bu}$ örnek olay çalışmasında (bütüncül tek durum deseni) araştırılan durum mümkün olduğunca çok yönlü olarak ele alınmış ve birbirini tamamlamaya yönelik çeşitli veri toplama araçlarıyla süreç desteklenmiştir. Araştırmacılar, çalışmanın bilgi toplama sürecinin doğal bir boyutu olarak hareket etmiş ve katılımcı gözlemci bir rol üstlenmişlerdir.

\section{Veri Toplama Araçları}

Araştırmada nitel veri toplama ve analiz teknikleri kullanılmıştır. Bir akademik dönem boyunca drama dersinde yapılan çalışmaların ve halka değerlendirmelerin video kayıtları alınmış, ve toplu görüşmeler kayıt edilmiştir. Ayrıca her drama uygulaması sonrasında öğrencilerden günlük tutmaları istenmiş ve bu günlükler portfolyo değerlendirilmesi olarak analiz edilmiştir. Gerekli görüldügü yerlerde ve zamanlarda öğrencilerle yapılan görüşmeler tekrarlanmıştır.

\section{Verilerin Analizi}

Nitel araştırmada geçerliğin ve güvenirliğin sağlanmasında kullanılan en önemli ölçülerinden biri çeşitleme "trangulation" dır. Çeşitleme, araştırma sorusuna yönelik olarak toplanan verilerin farklı yöntemlerle elde edilmesi ve bu şekilde elde edilen bulguların inandırıcılığının test edilmesi için kullanılır. Gözlem yoluyla elde edilen bilgilerin görüşme yoluyla teyit edilmesi ya da görüşmede ortaya çıkan bazı sonuçların gözlem yoluyla teyit edilmesi, çeşitleme için kullanılabilir. Denzin (1970) çeşitlemede temel ilkenin, farklı bireyler ve ortamlardan farklı yöntemlerle veri toplamak ve bu şekilde sonuçlarda ortaya çıkabilecek önyargıların ya da yanlış anlamaların önüne geçmek olduğunu belirtmektedir. Ayrıca çeşitleme, araştırma sonucu elde edilen sonuçların farklı boyutlardan değerlendirilmesine ve anlamlandırılmasına yardımcı olabilir. Böylece araştırmanın geçerliği ve güvenirliği konusunda okuyucu daha iyi bir fikir elde edebilir (Yıldırım ve Şimşek, 1999). 
Bu amaçla gözlemler ve görüşmeler video kayıt cihazı ile kaydedilmiş ve çözümlenmiş, ve elde edilen veriler geçerlik ve güvenirliği artırmak amacıyla birden çok araştırmacı tarafından analiz edilmiştir. Ayrıca, araştırma bulgularının iç-güvenirliğini ve geçerliğini artırmak amacıyla günlüklerdeki öğrenci görüşlerinden sıkça alıntılar yapılmıştır. Gerekli görülen aşamalarda verilere yeniden dönülerek ek değerlendirmeler ve karşılaştırmalar yapılarak bulgular derinlemesine analiz edilmiştir. 


\section{Bulgular ve Tartışma}

\section{Portfolyo değerlendirmelerinden elde edilen bulgular}

Katılımcılardan her hafta yapılan drama çalışmasından sonra kendilerini, süreci ve akranlarıyla ilgili değerlendirmelerini içeren günlükler tutmaları istenmiştir. Nitel araştırma tekniklerine göre incelenen bu verilerden elde edilen bulgular duygusal zeka ve iletişim konuları altında daha önce belirlenen kodlara göre analiz edilmiş ve gereken yerlerde bu kodlara eklemeler yapılarak çalışmaya devam edilmiştir.

\section{Ön kodlar}

Duygusal farkındalık: Kendini gözleme ve bir duyguyu oluştuğu anda tanıyabilme, andan ana değişen duyguları ele alabilme yeteneği. Duygularını en iyi tanıyan insanlar yaşamlarını en iyi yöneten insanlardır. Kişisel kararları hakkında gerçekten ne hissettiklerinden eminlerdir.

Duyguları yönetme: Bir duygunun arkasında ne olduğunu kavrama, karamsar, engellenmiş veya tedirgin yada kaygı1lı olduğumuzda kendimizi sakinleştirebilme kapasitesi.

Kişinin kendini güdeleyebilmesi: Duyguları herhangi bir amacın hizmetine sokmak üzere harekete geçirmek; duygusal öz-kontrol; doyumu erteleme ve çekiciliğe kapılmama .

Empati: Diğerlerinin duygularına ve ilgilerine duyarlı olma ve onların açısından bakabilme; farklılıkları takdir edebilme.

İlişkileri ele alma: Diğerlerinin duygularını yönetebilme; sosyal yeterlik ve sosyal beceriler.

Öncelikle öğrencilerin dram çalışmalarına genel olarak olumsuz bir tutumla gelmedikleri, çoğunlukla olumlu ya da tarafsız bir tutumla başladıkları gözlenmiştir.

"Drama sanırım böyle bir şey; her defasında farklı bir yön bulamak ve herkesten başka şeyler almak, hem eğleniyorsun, hem herkesten bir şeyler kaydediyorsun. İnsanın kendini eğlenerek keşfetmesi için başka nasıl bir yol vardır bilmiyorum."

İlk haftalardaki değerlendirmelerin genellikle, "duygusal farkındalık" ve "duygularını yönetme" boyutlarında farklılıklar ortaya koyduğu gözlenmiştir.

'Her geçen dersle birlikte kendimin daha farkinda olduğumu ve dolaylstyla potansiyelimi daha iyi gözlemleyip, kendime güvenimin daha çok arttığıdır... beden dilini kullanma, karşındakini ikna etme, ve yaratıcılık alanlarında çok yetersiz olduğumu düşünüyor ve bu tarz uygulamalardan genellikle kaçmayı tercih ediyordum ama bu drama sayesinde günlük yaşantımda uygulamaktan korktuğum rolleri, bu derste canlandırma yoluyla yaşayabileceğimi fark ettim

Kendini ve duygularını tanımaya yönelik kazanımlar için verilebilecek diğer bir örnek; 
“...ben görevli olmayı tercih ettim, çünkü ikna gücüme çok güvendiğim için ikna edilmesi gereken kişi ben olmak istedim, gruptan bir kişi ben ikna etmeye çalıştl, onları hızlı bir şekilde sorguladım, ve hemen açılklarını yakalayıp onları pes ettirdim, bu çalışma benim için çok orijinal ve eğitici oldu. Bütün bu etkinlikleri bir oyun değil de gerçekte yaşanmış bir olay gibi düşünmeye başladım.."

İlerleyen haftalardaki değerlendirmeler daha çok "empati kurma" ve beraberce bir düşünceyi paylaşabilme üzerine kurulu olduğu fark edilmiştir. Demokrasi eğitimi temalı çalışmadan sonra yapılan değerlendirmelerden birinde de belirtildiği gibi;

"Aslında önceki haftalarda da grup içinde kendimizi ifade etme, ortak bir karara varma ile ilgili çalışmalar yapmıştık ama bugünkü daha farklıydl, aynı konu üzerinde uzun süre tartışmaya odaklanmayı ve farklı bakış açılarından bakmayı denedik. ... Konu çok hassas bir konuydu, genelde köylüler ve çevreciler tarafindan bakmaya çalıştım."

Duyguların yönetimi ve empati kurma becerilerine verilebilecek örnekler ise:

Olay canlandırma çalışmamızda grup olarak alkollü araç kullanımı sonucu meydana gelen bir trafik kazası ve hastanede alınan ölüm haberi anını canlandırdık... Her geçen hafta canlandırmamı için verilen ya da bizim oluşturduğumuz konuya daha çok konsantre oluğumu, canlandırdiğım rolün içine daha iyi girebildiğimi hissediyorum...

Duyguların yönetimi altında görülebilecek diğer bir ifade;

Önceki etkinlikle bağlantılı olarak tüm sınıfin oluşturduğu bir tablo yaptık. Ben küçük bir köyde sevilen bir kişinin aniden ölümünü, yerde o kişinin cansız bedeni başında ağlaşan köylüler olarak hayal etmiştim. Yere bir kişinin yatacağını düşünüp onun başında ağıt yakan bir insanın psikolojisine büründüm... Vermek istediğim duyguyu tam olarak yansitabildiğimi düşünüyorum ....tablo tamamlanmıştı...

Sosyal beceriler ve sosyal yeterlik anlamında ilişkileri ele alma altında verilebilecek ifadelerden örnekler:

Sınıf olarak ise drama dersinden en büyük kazancımız birbirimizi çok daha yakından tanıma ve kaynaşma firsatı bulmamızdır. Daha önce sınıf ortamında birbiriyle nerdeyse hiç diyalogu olmayan kişiler dahil artık herkes birbiriyle iletişim kurmaya başladı.

Bir diğer katılımcının ifadesi ise:

...oluşturduğumuz tabloda önceki haftalardan farklı olarak tüm sınıf olarak oluşturduk, bu etkinlikte beni en çok hoşuma giden şey tabloya dışardan bakarak bu tablonun neresinde yer almalıyım diye düşünerek sırayla herkesin kendine bir yer bulmasıydı. Sinıfimı ilk defa bu kadar bir bütün olarak gördüm ve çok etkilendim. 
Duygusal zekanın alt boyutlarını oluşturan ve çalışmadaki nitel analizlerde kodları oluşturmakta kullanılan bu alt boyutlar gerek günlüklerde gerekse halka değerlendirmelerde oldukça sık ve tekrarlanarak gözlenmiştir.

\title{
Gözlem ve halka değerlendirmelere ilişkin bulgular
}

Tüm drama sürecinden elde edilen video kayıt görüntülerindeki halka değerlendirmelerde de portfolyo değerlendirme sonuçlarına paralel bulgulara ulaşmak mümkündür. Kendi duygularını anlama ve öz eleştiri yapabilme becerilerinin sorgulanması ve geliştirilmesine yönelik duygusal farkındalık ifadeleri örneklerde de görülmektedir.

\begin{abstract}
"Bu hafta bana öncelikle kendimle ilgili özelliklerimi kesfetmemi sağladl. Konsantrasyonumun yüksek olduğunu bilmeme rağmen bunu bu kadar aktif olarak daha önce kullanma firsatım olmamıştı. Konsantrasyonun bir işe başlarken ne kadar önemli olduğunu bir kez daha fark ettim. Buna ek olarak göz temaslyla ilgili eksiklerim olduğunu ve bunun üstüne gitmem gerektiğini gördüm. Ayrıca güven çalışmalarında sorun yaşamadığımı ancak başkasının sorumluluğunu almada tedirginlik yaşadığımı düşünmemi să̆ladı.",
\end{abstract}

Halka değerlendirmelerde ortaya çıkan ve drama sürecinin dersin dışına, günlük hayata transferini ifade eden değerlendirmelere örnek olarak ise:

...her şeyden önce arkadaşlarımla olan iletişimim ve kendime olan güvenim arttı, kendimi daha kolay ifade edebiliyorum, daha kolay eleştiri ve yorum yapabiliyorum, hayal gücümü ve duyularımı daha aktif kullanabiliyorum. Kendimi daha rahat ve özgür hissediyorum ...

.. kalabalık gruplardan ve getirdiği karmaşadan şikayet etsem de halka değerlendirmelerde yapılan yorumlardan anladım ki, aslında hayatın kendisi de böyle. Bir karmaşay yaş̧yoruz ve sürekli bir takım kararlar vermek durumundayız. Drama da bir nevi günlük hayatın canlandırılması olduğuna göre böyle karmaşık durumların söz konusu olması kaçınılmaz. Belki de bu tip durumlara drama etkinliklerinde görüp üzerine gitmek, günlük hayatta işimizi kolaylaştıracak.

Empati kurma becerisine verilecek bir gözlem ise;

Ben işletmecinin tarafi olmama rağmen ve rolümü o karakteri yansitabilecek şekilde oynanama ră̆men, yaptı̆̆ımız diğer etkinliklerde karşı çıktı̆̆ım karakteri dahi oynadım. Bu da bana olaya tek bir bakış açısından bakmak yerine, farklı bakış açıları geliştirmemde ve ona göre hareket etmemde yardımcı oldu.

Diğer taraftan, drama çalışmalarının günlük hayatla çok da aynı olmadığını düşünen bir görüşe örnek verirsek; 
Aslında bir olay ya da durum karşısında objektif olmak ve empati kurmak o kadar da zor bir şey değil, ya da sorunlara çözümler getirmek, tabi olayın içinde biz yoksak. Eğer bir olay ya durum bizi direk etkiliyorsa sanmıyorum ki bu kadar objektif olabilirim ya da rahatça çözümler bulabilirim.

Benzeri görüşleri ifade eden diğer bir örnek değerlendirme ise;

....Drama sayesinde oluşturduğumuz farklı gruplar ve her seferinde farklı eşlerle ikili çalışmalarımızın olması aramızdaki paylaşımı ve iletişimi artırdı. Özellikle bu haftaki etkinliklerde daha çok ortak karar verebilme, uyumlu çalışma ve insanlarl ikna edebilme becerisini geliştirmeye yönelikti...bir şey daha belirtmek istiyorum, bu dersten çıkınca uzun süre dersin etkisinden kurtulamiyorum, ve çevremdeki insanlara her ders sonunda yaptıklarımızı tekrar yaşarmış gibi anlatıyorum.... Sınıfta çok güzel şeyler ürettiğimizi hissediyorum.

\section{Toplu görüşmelerden elde edilen bulgular}

Dönem sonunda yapılan toplu görüşme lerden elde edilen bulgular belli başlı sorular altında analiz edilmiş ve diğer bulgularla paralellik sağlanarak sunulmuştur.

Yaptı̆̆ınız bu drama çalışmalarının kendinizde yarattı̆̆ını düşündüğünü̈z farklılıklar var mı, örneklendirebilir misiniz?

$\mathrm{Bu}$ soru altında verilen cevaplardan örnekler,

A1 : Öncelikle ben kendimin dramayla ilgili her hangi bir şeye bu kadar içten katılabileceğimi düşünmemiştim. Bana çok şey kattığını düşünüyorum, sadece öğrencilik hayatıma değil, günlük yaşantımda da farklılıklar görebiliyorum. Bunu çevremdekiler de söylüyorlar. Özellikle drama dersinde yaptığımız o anada başka bir şeyi hayal ederek hisleri çağırmak ve ordaymışız ya da o şeyi yaşıyormuşuz gibi yaparak kendimizi farklı bir ortamda hayal etmek. Bu tarz etkinliklerin beni sakinleştirdiğini düşünüyorum. Önceden çok çabuk tepki veren ve çabuk sinirlenen bir insandım ama şimdi olumsuz bir şeyle karşılaşınca sakinleşebilmek için kendimde yapabileceğim şeyler var, aklıma başka şeyleri getirip hemen tepki vermeyi engelleyebiliyorum (duygusal farkındalık ve duygu yönetimi).

Drama çalışmalarında aniden duygu ifadelerimizi değiştirmemiz gereken etkinlikler yaptık, şimdi günlük hayatımızda da bu tarz şeylere gereksinim duyduğumuzu görüyorum. Karşılaştığımız her şeye hemen ilk aklımıza geldiği gibi tepki vermek yerine duygularımızı kontrol ederek daha akılcı tepkiler vermeye çalışlyorum (duygu yönetimi).

Ayrıca tanımadığım insanların olduğu ortamlara girdiğimde daha çabuk uyum sağlamama faydası olduğunu düşünüyorum. Daha rahat hareket ediyorum. Karşılaştığım insanları daha iyi tanımaya teşvik ettiğini düşünüyorum. İște eleştiriye açık mı, mimikleri söylediklerini destekliyor 
mu? Özellikle iletişimle ilgili bana çok katkısı var, sınıfta öylesine tanıdığım pek çok arkadaşım hakkında daha doğru ve derin fikirlerim oldu (ilişskileri ele alma).

Bir şey daha eklemek istiyorum, insanların sandığımdan daha karmaşık olduğunu da gördüm. Herkesi kendimiz gibi sanmak hata olur. Özellikle halka değerlendirmeler çok faydalı oldu. Çünkü dramada herkes çok doğal ve karşınızdaki insanı daha rahat tanıyabiliyorsunuz. Insanların kişiliklerinin hangi olaylarda nasıl tepki verilebileceğini görmek için ortam sağlanmış oluyor. Dahası dışarıda da insanları nasıl tanıyabileceğinizi öğreniyorsunuz (empati ve ilişkileri ele alma)

B1: Ben de insanlarla hemen kaynaşamayan iletişim kuramayan birisiyimdir. Ama drama derslerinde kendimle ilgili fark ettiğim şeyler sandığım gibi olmadığımı gösterdi. Geçen hafta gittiğimiz bir sempozyum vardı, orda hiç tanımadı̆̆ımız insanlarla bir grup çalışması yapmamız gerekiyordu ve sandiğımın aksine hemen işe katılabildim., iletişim kurabildim. Kendimi çok rahat hissettim. Başka bir şeyde bu derste gördüklerimizden sonra özellikle karşımdakini tanımaya anlamaya onlarla empati kurmaya emek harcadığımı fark ettim. İnsanlarla ilgili hemen kararlar vermiyorum artık (empati ve ilişkileri ele alma).

\section{Drama dersinde yaşadığını deneyimlerin ders sonrasında da size etkisi olabileceğini düşündüğ̈̈n̈̈̈z yönleri var mı? Örnekler verebilir misiniz?}

$\mathrm{C} 1$ : Hocam mesela, asla kendime konduramayacağım bir etkinlik varsa o da tiyatroydu, ve drama derslerinde fark ettim ki ben aslında tiyatroyu sevebilirmişim, hatta yapabilirmişim.

Bir de artık ayrıntılara daha çok dikkat ettiğimi fark ettim. Bir film izlerken önceden hiç görmediğim şeyleri fark ediyorum. Oyuncunun duruşu, ifadesi, tepkileri, ortam artık dikkatimi çekiyor. Film izlerken film hatalarını bulmaya başladım. Şöyle yapsaydı daha iyi olurdu dediğim yerler oluyor (ilişsileri ele alma).

Insanlarla konuşurken sadece söylediklerine değil nastl söylediğine de baklyorum. Jestleri mimikleri, beden diline bakarak acaba doğru mu söylüyor diye düşünüyorum. Davranışları söylediklerini destekliyor mu diye bakıyorum (empati ve ilişkileri ele alma).

D1: Ben çocuklar hariç, insanlara tahammül etmekte çok zorlanan biriyimdir. Ama artık tahammül sınırlarımın arttı̆̆ını düşünüyorum. Bir şeyle karşılaştığımda içine atmak değil ama kendimi tutabildiğimi düşünüyorum (duygu yönetimi).

Bir de drama dersi başladığımdan beri üç defa tiyatroya gittim, daha önce hiç gitmemiştim, zevk alacağımı da düşünmüyordum. Bu benim için çok büyük bir şey. 
E1: Beden dilimi artık daha iyi kullanabildiğimi düşünüyorum (ilişsileri ele alma). Şöyle bir örnek vermek istiyorum. İki hafta önce arkadaşım bir trafik kazası geçirdi. Ailesine haber vermeden önce beklememiz gerekiyordu, yani ailesine durumu belli etmememiz gerekiyordu. Arkadaşımın yanından ayrıldıktan sonra ailesinin yanına giderken nasıl fark ettirmeyeceğimi düşündüm, çünkü benim yüzümden her şey anlaşılır. Yol boyunca dramada yaptığımız şeyler aklıma geldi ve benim o üzgün halimi değisstirebilecek şeyler işse mutlu olduğum anları hatırlamaya çalıştım ve yüz ifademi kontrol etmeye duygularımı yönlendirmeye çalıştım. Hem hayal ettim hem bunu beden dilime yansittım (duygu yönetimi ve ilişkileri ele alma). $\mathrm{N}$ e kadar başarılı olduğum tartışılır ama o ana elimdeki tek şey drama dersinde yaşadıklarımızdı.

F1: Ben bu sınıfa bu sene transfer oldum, bazı arkadaşlarımın adını dahi bilmiyordum. Şimdi herkes hakkında bir fikrim var. Bunu başka bir şekilde bu kadar doğal bir şekilde gerçekleştiremezdim. Bir de ilk drama derslerinde ben tutulup kalıyordum. Ne yapacağım nasıl yapacağım, kasılıyordum, diğer derslerde hazırlayacağımız etkinliklerde aklıma hiç bir şey gelmiyordu. Ama şimdi çocuklar için bir şey hazırlamam gerektiğinde özellikle etkinliklerde çocuklar şundan hoşlanır, bundan hoşlanmaz diyebiliyorum, klsa sürede etkinlik bulabiliyorum. Onların bir uygulamayı yaparken neler hissedeceklerini tahmin edebiliyorum. Böylece yaratıcılı̆̆ımın da arttığını düşünüyorum (empati ve ilişkileri ele alma).

G1: Ben de benzeri bir örnek vermek istiyorum. Uygulama yapmamız gereken bir ortamdı. Önümüze birkaç birbiriyle ilgisiz malzeme konmuştu, ve benim grup arkadaşlarımla hemen bir etkinlik oluşturmam bekleniyordu. Inanın 20 farklı etkinlik ortaya çıkardık ve bunu çocuklarla bir buçuk saat oynadık. Drama dersinden önce böyle bir şey yapabileceğime kesinlikle inanmazdım empati ve iliş̧kileri ele alma).

A2: Bir şey eklemek istiyorum, drama bana bir de bir olaya farklı şekillerde bakabilmeyi gösterdi. Sibel Hocanın liderliğinde yaptığımız Bergama'da geçen fabrika kapatma olayıyla ilgili olan etkinlikte orda bir sorunla ilgili bir sürü çözüm bulunabileceğini gördük. Bir olaya sadece bir açıdan değil de pek çok açıdan bakılabileceğini gördüm (empati ve ilişkileri ele alma).

Dört hafta önce kapılarla ilgili bir drama etkinliği yapmıştık, arkadaşlarımızın liderlik yaptığı bir haftaydı, şimdi bir kapı gördüğümde hemen hayal gücüm çalışmaya başlıyor, acaba bu kapının ardında neler vardır diye düşünce üretirken buluyorum kendimi. Sadece sözlerle bile bizi başka ortamlara taşıyabilen arkadaşlarımız oldu, çok güzel bir tattı.

H1: Empatiyle ilgili bir örnek vermek istiyorum, önceden hocalarımızdan bir şey istediğimizde eğer olumsuz cevap alırsak hemen bozulurdum, kızardım, niye olmuyor diye. Şimdi birinden ya da bir hocamda bir şey istediğimde ya da daha istemeden kendimi onun yerine koyarak onun neler 
hissettiği ya da nasıl bir durumda olabileceğini düşünüyorum. Belki çok yoğundur, belki benim bilmediğim bir durum vardır diye onun açısından da olaya bakmaya çalışlyorum (empati kurma).

Burada söz ettiğiniz farklılıklar ve gelişmelerle ilgili olarak ileriki meslek hayatınızda ya da günlük hayatınızda size yardımcı olacağını düşündüğünüz kazanımlar var mı?

D2: Mesleğimi yaparken zorluk çekeceğimi düşündüğüm tek nokta velilerle iletişim kurmak. Stajlarda ya da yazın katıldığımız bazı çalışmalarda yaşadığım en büyük aslında tek problem velilerle iletişim kuramamak. Geçen haftaki stajdan bir örnek vereyim. Çocukları ikna etmekte hiç sıkıntı çekmiyorum, onları bir yerden bir şekilde yönlendirebiliyorsunuz, ama veliler bazen çok gereksiz inat edebiliyor, sırf itiraz etmek için sizinle tartışabiliyorlar. Geçen hafta benzeri bir durum yaşadım. Sonra fark ettim eskisi gibi hemen sinirlenmiyorum, önce sakinleştim, konuyu değiştirdim, onlara başka bir etkinliğe yönlendirdim, sonra bir şekilde konuşarak onları asıl isteğim etkinliği yapmaya ikna ettim. Ben de kendime inanamadım. Şimdi bu aşamada bunu yapabildiysem ilerde de insanları ikna etmekte daha başarılı olacağıma inanıyorum ( duygu yönetimi ve ilişsileri ele alma).

J1: İkna etmek deyince ben de bir şey eklemek istiyorum. Benim dramadan önce ikna etme kabiliyetim yok denecek kadar azdı. Hatta ilk haftaki çalışmalarda hiç başarılı olamıyordum. Daha doğrusu konsantre olamadığım için odaklanamıyor, karşımdakine duygumu aktaramıyordum ve bu insanda yetersizlik duygusu yaratıyor. Ama geçen hafta özelikle hocamız da söyledi, o kadar ciddi bir şekilde rolümü yaptım ve karşımdakine duygumu geçirdim ki gayet ikna ediciydim, ve bu çok hoşuma gitti. Bunun nasıl gerçekleştirdiğimi düşündüm. Dramada yaptığımız ısınma, güven odaklanma çalışmalarında yaptığımız daha sonra kısa zamanda birden çok fikir üretme gibi etkinliklerden edindiklerimi kullandığımı fark ettim. Birine odaklandığınız da ve amacınız onu ikna etmek olduğunda kafanızdan aynı anda pek çok düşünce geçiyor ve bunu karşınızdakine aktarmaya çalışıyorsunuz. Siz kendinize ne kadar inanırsanız, onu inandırmanız da o kadar mümkün oluyor ( duygu yönetimi ve ilişkileri ele alma).

B2: Arkadaşlarımın da bu duygumu paylaştıklarını düşünerek bir şey söylemek istiyorum, drama dersinde yaptığımız işi ciddiye almayı da öğrendik. İlk haftalardaki halimizi biliyorsunuz, şimdi daha iyi anlıyorum tabi, aynı anaokulu çocukları gibiydik. Şimdi hem kendime hem arkadaşlarıma bakıyorum, yaptığımız işi daha çok ciddiye alıyoruz, daha çok emek veriyoruz. Dolayısıyla da daha çok zevk alıyoruz.

K1: Ben ikna etmeyle ilgili bir şey söylemek istiyorum. Daha önceki iki yaz tatilinde de çalışmak istediğimi söylediğimde ailemden tepki almış ve onları razı edememiştim. Ama bu yaz için tekrar 
isteğimi söylediğimde onları razı etmeyi başardım. Herkesle gayet uygun bir dille konuştum, şimdi herkes olumlu baklyor, sanırım onlart ikna edebileceğim, ve bunun drama deneyimlerim sayesinde olduğınu düşünüyorum ( ilişkileri ele alma).

Grup çalışmalarıyla ilgili düşüncelerinizi almak istiyorum, derslerinizle ilgili olabilir, günlük hayatınızdaki durumlarla ilgili olabilir?

L1: Daha önce grup çalışmalarl yaparken benim söylediğim fikir kabul görmediğinde üzülür ve o işten soğurdum, ama şimdilerde yaptı̆̆ımı grup çalışmalarında fikrim kabul edilmese de o işe motivasyonumu kaybetmiyorum, çünkü o hala bizim işimiz, başkasının fikri kabul edilse de ortaya çıkan iş bizim diye düşünüyorum ( ilişkileri ele alma). Bunun kesinlikle dramadaki grup çalışmalarıyla ilgili olduğunu düşünüyorum. O kadar çok çeşitli etkinliklerde farklı gruplar oluşturarak birbirimizle etkileşime girmeyi yaşadık ki artık, bana çok doğal bir süreç olarak geliyor. Başkalarının fikirlerini önemsemeyle ilgili bir şey ( ilişskileri ele alma). Dramadaki grup çalışmalarında yaptı̆̆ınız şeyi ürün olarak da hemen görebiliyorsunuz ve çok kisa sürede geri bildirim almış oluyorsunuz. Çok daha verimli olduğunu düşünüyorum.

M1: Şu anda başka derslerde yaptığımız grup çalışmaları ilk sene yaptıklarımızdan çok farklı. Önceleri herkes neyi biliyorsa onu yapardı, diğerleriyle paylaşmaz, yapar getirir, burada birleştirir, sunardık. Son grup çalı̧̧malarımızda artık öyle değil, her aşamasında hep beraber hareket ediyor, karar veriyor ve uyguluyoruz, böylece herkes her aşamasından haberdar oluyor ve her aşamasında ortak sorumlu oluyor (ilişkileri ele alma).

J2: Beraber çallşırken benim fikrimi ya da hareketimi beğenmese de beni eleştirmek yerine bana alternatif getirerek bana bir şeyler anlatmaya çalıştı̆̆ını anlayabiliyorum. Düşündüklerimi yansıtabiliyorum. Bazen farkında olmadan birbirimizi tamamlayan hareketler yaptığımızı görüyorum (ilişkileri ele alma, empati).

Yukarıdaki toplu görüşmelerden elde edilen bulgular gözlem, halka değerlendirme ve günlük değerlendirmeleriyle paralellik oluşturacak şekilde aynı kodlarla analiz edilmiştir. 


\section{Sonuç}

Kendini gerçekleştirme kavramı içinde bireyin kendini potansiyelini tanıması ve gelişme kaydedebilmesi için duygunun kişi tarafından anlaşılması ve ifade edebilmesi, duyuların yönetilmesi, duyguların güdülenebilmesi, empati kurabilme ve bu becerileri ilişkilerde ele alma önemlidir. $\mathrm{Bu}$ beceriler aynı zamanda sağlıklı ve etkili bir iletişiminde olmazsa olmazlarıdır.

Öğretme ve öğrenme süreçlerinde gerçekleştirilen tüm etkinlikler birer iletişim etkinliğidir. Öğrenci bir eğitim ortamında öğretmen ve çevreyle etkileşimde bulunur. Öğretmenin bilişsel, duyuşsal ve psiko-motor tüm davranışlarının öğrencilerle paylaşması bu etkileşimin gerekçelerinden biridir. Drama ve iletişim çalışmalarında ortaya konan tüm ürünler iletişimin tüm özellikleri kapsamında paylaşılmaktadır. Çünkü çalışmaların özünde birlikte üretme ve paylaşama isteği vardır. Öğretmenin hoşgörülü, sabırlı, sevecen, kendini geliştirmeye eğilimli, planlı, sistemli, değişikliklere uyum sağlayabilen, destekleyici, günlük yaşantısında karşılaştığı sorunları çözebilme, etkin iletişim becerilerine ve öğrencilere karşı dostça davranabilme özelliklerine sahip olması gerektiği sıkça vurgulanmaktadır

Öğrencilerden alınan görüşler doğrultusunda onların da dramayla öğrenmenin diğer öğrenme yollarından farkına işaret ettikleri gözlenmiştir. Drama grubu deneyim kazandıkça iletişim artacaktır. Duygusal zekanın gelişimi için sağlıklı bir iletişime gerek duyulduğu gibi, iyi ve güvenilir bir iletişim için de duygusal zekanın gelişimine gereksinim vardır. Duygusal zekanın alt boyutları olan duygusal farkındalık, duygu yönetimi, duygularını yönlendirme, empati (duygudaşlık) ve ilişkilerde kullanma aynı zamanda sağlıklı bir iletişimin olmazsa olmaz parçalarıdır. Kısacası, duygusal zekanın gelişimini amaçlayan hiçbir çalışma, iletişim becerilerinin gelişiminden ayrı tutulamaz.

Özellikle öğrencilerin drama sürecinde yaşadıkları gelişime bir bütün olarak bakıldığında duygusal zekanın tüm alt boyutlarında ve duygusal zekanın gelişiminin doğal bir sonucu olan iletişim becerilerinde ki gelişim oldukça net bir şekilde fark edilmektedir. Gerek öğrenci görüşleri ve günlükleriyle katılımcı beyanları, gerekse süreçte katılımcı gözlemci olarak bulunan araştırmacıların ortaya çıkardığı gözlem sonuçlarıyla tüm öğrencilerde genel olarak bir farklılık oluştuğu ortaya çıkmıştır.

Nitel araştırma geleneğinin bir gereği olarak bu tür durum çalışmalarında bulunan bulgular sadece söz konusu olayı daha derinlemesine ve çoklu veri toplama araçlarıyla araştırmanın desteklenmesini öngörmektedir, genelleme amacı güdülmemektedir. Bu bağlamda yapılan bu çalışma öğrencilerin dramayla ilk tanışmaları olarak algılanmalı ve yaşanan deneyimlerin kazanımlarının ortaya çıkması için deneyim sayısının artırılması gerektiği unutulmamalıdır. 


\section{Kaynaklar}

Akyol Köksal, A. (2003). “Okulöncesi Eğitimde Drama ve Örnek Çalı̧̧malar”. Okulöncesinde Drama ve Tiyatro. Türkiye 5. Drama Liderleri Buluşması Bildirileri. Oluşum Tiyatrosu ve Drama Atölyesi. Ankara: Fersa Matbaacılık, s.63-76

Andersen-Warren M, Mitchell S (eds) 1995 Dramatherapy: Clinical Studies. J Kingsley P, London

Çam, S. (1997). İletişim becerileri eğitim programının öğretmen adaylarının ego durumlarına ve problem çözme becerisi algılarına etkisi. Ankara Üniversitesi Sosyal Bilimler Enstitüsü. Ankara : Yayınlanmamış Doktora Tezi.

Goleman, D. (2000). İşbaşında duygusal zeka. İstanbul:Varlık Yayınları.

Güneysu, S. (1999). Çok yönlü zeka ve eğitimde drama. Türkiye 1. Drama Liderler Buluşması. Ankara:Oluşum Tiyatrosu ve Drama Atölyesi, 45-52.

Güneysu, S., Çağlayan, E., Kaygısız, P. (2005). Beyin araştırmalarının eğitime yansıması. Ankara: SMG Yayıncilı.

Konrad, S. (2001). Duygusal zeka sayesinde başarılı bir hayat: Duygularla güçlenmek. İstanbul: Hayat yayınc1lı.

Mayer, J.\& Salovey, P. (1993). The intelligence of emotional intelligence. Inteligence, 17, 433-442.

Özdemir, L. (2003). Yaratıcı drama dersinin duygusal zeka gelişimine etkisi. Uludağ Üniversitesi Sosyal Bilimler Enstitüsü. Bursa :Yayınlanmamış Yüksek Lisans Tezi.

Öztürk, A. (1999). Öğretmen yetiştirmede yaratıcı drama yöntemiyle işlenecek tiyatro dersinin öğretmen adaylarındaki sözel iletişim becerilerine etkileri. Eğitimde Tiyatroda Yaratıcı Drama, Çağdaş Drama Derneği Bülteni, 3(4), 33-35.

Riseborough R (1993). The use of drama in health education. Nursing Standard 7(15-16): 30-32

Sağlam, T.(1997). Eğitimde drama. VI. Uluslararası Eğitimde Drama Semineri, Drama Maske Müze. Yayına Hazırlayan: İnci San. Ankara: Çağdaş Drama Derneği, 33-35.

San, İ. (1999). Sanatlar Eğitimi Üzerine Yeni Düşünceler, 1. Ulusal Sanat Eğitimi ve Sorunları Sempozyumu, Onsekiz Mart Üniversitesi Eğitim Fakültesi Yayın1arı, s.1-8, Çanakkale.

Ulaş, A. H., Topal, Y. (2006). Effects of creative, educational drama activities to develop oral skills in primary school. [Electronic version]. EKEV Akademi Dergisi, year: 10, 29.

Yıldırım, A., Şimşek, H. (1999). Sosyal bilimlerde nitel araştırma yöntemleri. Ankara: Seçkin Yayınevi, s. 85.

Wasylko, Y., Stickley, T. (2003). Theatre and Pedagogy: using drama in mental health nurse education. Nurse Education today(23), 443-448.

Wright P. R. (2006). Drama education and development of self: Myth or reality?. Social Psychology of Education. 9:43-65 DOI: 10.1007/s11218-005-4791-y 


\section{Summary}

\section{The Effect of Drama on The Development of Emotional Intelligence}

Sibel GÜNEYSU ${ }^{1}$

\section{Belkıs TEKMEN ${ }^{2}$}

Başkent Üniversitesi

Drama is a feature of civilization and it has long been used an education tool. The concept of using drama in education consists with the humanistic and person-centered philosophy of Carl Rogers. Rogers believed in the individual's potential for learning. If the teacher lays aside the didactic power position and temporarily gives control to the creative energy of the student, drama as a learning medium can be empowering and promote personal growth. The students' experiences and subsequent reflections guide the session and as a facilitator, the teacher follows the students' work. Using drama education facilitates active learning by means of engaging the imagination, stimulating emotions, stimulating right brain activity, providing a safe context for exploring, alternative actions and interventions, offering a fresh perspective on problems, providing framework to facilitate change, exploring a range of possible outcomes, helping individuals to resolve unresolved, feelings and thoughts (Jennings, 1987).

In this study, the effect of drama on the development of emotional intelligence, which gains more importance nowadays, is investigated. Thirty undergraduate students from preschool education department taking drama course in the Education Faculty of Baskent University participated in the study. Qualitative research methods, which are group interviews, observations, video recordings and portfolio evaluation, are used to understand the effects of drama education on individuals' emotional intelligence and communication skills.

The instructor of the drama course was highly experienced and certified on drama education and using drama in education. Two researchers acted as non-participant observers and collected data through the whole semester lasting fourteen weeks. All sessions are recorded by video camera and analyzed by researchers and the instructor of the course. Portfolios and interviews are also transcribed and analyzed by two researchers and the analyzing process of all the data sources are tried to be conducted parallel and sequenced. On the other hand, students were free to discuss and interview informally with both the researcher s and the instructor about the course.

For reliability and validity issues of this qualitative study, data triangulation by using various data collection tools, analyzing them by two researchers and explaining the whole process of data analyzing by detailed quotations were established.

\footnotetext{
${ }^{1}$ Prof. Dr., Başkent Üniversitesi Eğitim Fakültesi, sibelg@baskent.edu.tr

${ }^{2}$ Araş. Gör., Başkent Üniversitesi Eğitim Fakültesi, tekmen@baskent.edu.tr
} 
Results were reported according to the emotional intelligence subtitles of emotional awareness, emotion management, self- motivation, empathy and healthy communication skills. Developing emotional intelligence needs a healthy communication, whereas a healthy and reliable communication needs a development in emotional intelligence. These two complementary pieces, emotional intelligence and communication skills, are analyzed thoroughly before, during and after the drama education. Especially for the first four categories of emotional intelligence all the participants showed significant development both in the drama sessions and in the self evaluation parts in the sessions and in the portfolios. Most of them mentioned about the outcomes of the course positively and they were consistent with outcomes defined at the beginning of the course.

Being aware of the self-emotions, expressing them and establishing a healthy communication are the most essential components of knowing ones self potential and improving it. Since there is the idea of producing and sharing in the heart of drama studies, it makes a suitable environment for the development of emotional intelligence. 
COVER LETTER

Title of the submission: The Effect of Drama on The Development of Emotional Intelligence.

Names of the authors:

$1^{\text {st }}$ author: Sibel Güneysu (PhD), Professor

$2^{\text {nd }}$ author: Belkis Tekmen, Research Assistant

E-mail addresses:

sibelg@baskent.edu.tr

tekmen@baskent.edu.tr

Phone number:

03122341010 / 1070

03122341010 / 1067

Mailing address:

Başkent Üniversitesi 


\section{Bağlıca Kampusü}

Eskişehir yolu 20. Km. 06530 Ankara 
